\title{
Enhanced methane emissions from oil and gas exploration areas to the atmosphere - The central Bohai Sea
}

\author{
Yong Zhang a,b, Hua-de Zhao ${ }^{a}$, Wei-dong Zhai ${ }^{\mathrm{a}, *}$, Kun-peng Zang ${ }^{\mathrm{a}}$, Ju-ying Wang ${ }^{\mathrm{a}}$ \\ ${ }^{a}$ Key Laboratory for Ecological Environment in Coastal Areas (State Oceanic Administration), National Marine Environmental Monitoring Center, Dalian 116023, China

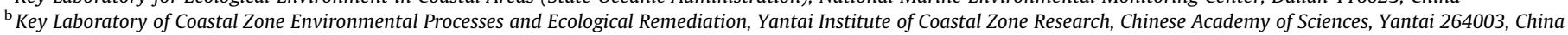

\section{A R T I C L E I N F O}

\section{Keywords:}

Methane

Underway measurement

Sea-air flux

Oil spill

Bohai Sea

\begin{abstract}
A B S T R A C T
The distributions of dissolved methane in the central Bohai Sea were investigated in November 2011, May 2012, July 2012, and August 2012. Methane concentration in surface seawater, determined using an underway measurement system combined with wavelength-scanned cavity ring-down spectroscopy, showed marked spatiotemporal variations with saturation ratio from $107 \%$ to $1193 \%$. The central Bohai Sea was thus a source of atmospheric methane during the survey periods. Several episodic oil and gas spill events increased surface methane concentration by up to 4.7 times and raised the local methane outgassing rate by up to 14.6 times. This study demonstrated a method to detect seafloor $\mathrm{CH}_{4}$ leakages at the sea surface, which may have applicability in many shallow sea areas with oil and gas exploration activities around the world.
\end{abstract}

(c) 2014 Elsevier Ltd. All rights reserved.

\section{Introduction}

Methane $\left(\mathrm{CH}_{4}\right)$ is an infrared-active trace gas with a long atmospheric lifetime of ca. 10 years (Lelieveld et al., 1998). Atmospheric $\mathrm{CH}_{4}$ concentration has been increasing steadily from 1.52 parts per million by volume (ppmv) in 1978 (Blake and Rowland, 1988) to 1.81 ppmv nowadays (World Meteorological Organization, 2012). Despite its low concentration in the atmosphere, $\mathrm{CH}_{4}$ absorbs infrared radiation 25-40 times more efficiently than does $\mathrm{CO}_{2}$. At present, $\mathrm{CH}_{4}$ accounts for $15-20 \%$ of the anthropogenic greenhouse effect (Houghton et al., 1990; Shindell et al., 2009) and is ranked as the second largest contributor to atmospheric radiative forcing (IPCC, 2007).

Due to natural physical and biological processes and anthropogenic activities, sea surface concentrations of dissolved $\mathrm{CH}_{4}\left(\left[\mathrm{CH}_{4}\right]\right.$ for short) usually exceed atmospheric equilibrium (e.g., Lamontagne et al., 1973; Conrad and Seiler, 1988; Plass-Dülmer et al., 1993, 1995; Reeburgh, 2007). In open oceans, $\mathrm{CH}_{4}$ sources in shallow water depths are provided by microbial subsurface $\mathrm{CH}_{4}$ generation taking place in zooplankton guts, the oxygen-deficient interior of particles, or under phosphate-limiting conditions (Karl et al., 2008; Damm et al., 2010). In waters overlying continental shelves, however, the organic-rich sediment serves as a major source of $\mathrm{CH}_{4}$ in the water column compared to net production

\footnotetext{
* Corresponding author. Tel.: +86 13387862072; fax: +86 41184783277.

E-mail address: wdzhai@126.com (W.-d. Zhai).
}

in the mixed layer (Martens and Berner, 1974; Martens and Klump, 1980; Reeburgh, 2007). The shallow-water $\left[\mathrm{CH}_{4}\right]$ can also be elevated due to gas seepages and/or oil spills (Bernard et al., 1976; Reed and Kaplan, 1977; Rehder et al., 1998, 2002; Kessler et al., 2011; Gülzow et al., 2013) and advection of $\mathrm{CH}_{4}$-rich freshwaters (Sackett and Brooks, 1975; Cline et al., 1986; Zhang et al., 2008). Since $\mathrm{CH}_{4}$ is oxidized to dissolved inorganic carbon via microbial oxidation processes (Sieburth et al., 1987; Jones, 1991; Reeburgh, 2007) and/or lost via sea-air gas exchange (Crutzen, 1991; Bange et al., 1994), determining $\left[\mathrm{CH}_{4}\right]$ in surface water with high spatiotemporal data coverage is critical in adding to our understanding of the marine $\mathrm{CH}_{4}$ cycle and furthermore of the marine carbon cycle. Additionally, quantifying the leaked $\mathrm{CH}_{4}$ dissolved in the water might be an effective approach to assess the size of an oil spill, which is essential to understand its environmental impacts (Valentine, 2010).

During the process of marine oil and gas extraction, accidental gas seepages and/or oil spills are usually accompanied by massive short-term $\mathrm{CH}_{4}$ injection into the overlying water column, as occurred in the Gulf of Mexico in 2010 (Valentine et al., 2010; Kessler et al., 2011). So far the impacts of marine oil and gas exploration on the sea-air outgassing of $\mathrm{CH}_{4}$ are still poorly understood, due to the fact that determination of $\mathrm{CH}_{4}$ concentration has long been limited to the gas chromatography (GC) method equipped with flame ionization detector (FID), based on which it is difficult for researchers to obtain sufficient spatiotemporal resolution of $\left[\mathrm{CH}_{4}\right]$. Recently, great efforts have been made to develop fast, 
precise, and on-the-spot monitoring techniques for $\left[\mathrm{CH}_{4}\right]$ (e.g., Gülzow et al., 2011, 2013; Yvon-Lewis et al., 2011).

In recent years, wavelength-scanned cavity ring-down spectroscopy (WS-CRDS) has been proven to be a highly stable, reliable, and accurate method for measuring trace-level greenhouse gases (e.g., Crosson, 2008; Chen et al., 2010; Winderlich et al., 2010; Zang et al., 2011). Briefly, the gas sample is introduced into a highfinesse optical cavity consisting of two or more mirrors. Then an infrared band laser is injected into the cavity. The laser passes the cavity numerous times due to reflection at highly reflective mirrors, producing an absorption path length of tens of kilometers. After shutting off the laser, the light intensity in the cavity decays exponentially with time. The concentration of the gas sample is proportional to the area under the measured spectral features. So far WS-CRDS has been successfully used for the continuous measurement of $\mathrm{CH}_{4}$ concentrations in the atmosphere (Crosson, 2008; Chen et al., 2010; Winderlich et al., 2010; Zang et al., 2013) and in surface seawater (Gülzow et al., 2011, 2013; Yvon-Lewis et al., 2011).

In this study, we determined sea surface $\left[\mathrm{CH}_{4}\right]$ in the central Bohai Sea with a home-made underway measurement system in combination with a WS-CRDS analyzer. Our measurements represent the first attempt to do so in China Seas. This high-resolution data set provides an opportunity to examine impacts of marine oil and gas exploration on the distribution and sea-air flux of $\mathrm{CH}_{4}$ in this shallow sea.

\section{Materials and methods}

\subsection{Study area}

The semi-enclosed Bohai Sea covers an area of $77,284 \mathrm{~km}^{2}$, and has an average water depth of $18 \mathrm{~m}$. It is open to the North Yellow Sea through the Bohai Strait, and is surrounded by several highly industrialized cities such as Tianjin, Tangshan, Qinhuangdao, Dongying, and Dalian (Fig. 1). As the largest Chinese marine crude oil production base, the Bohai Sea had 23 marine gas fields, 1932 oil wells, and 175 marine platforms that had been built/operated until
2009 (CCICED, 2010) (Fig. 1). In the past 15 years, quite a number of serious oil-spill accidents have occurred in this shallow sea (Kou et al., 2010), including the famous "Penglai 19-3" oil-spill accident in June-August 2011. So far the impacts of oil and gas exploration on the distribution of $\left[\mathrm{CH}_{4}\right]$ in the Bohai Sea are still unknown, although Li et al. (2010) reported the distribution of $\left[\mathrm{CH}_{4}\right]$ in the Bohai Sea in summer 2008.

Recently, oil and gas exploration areas in the Bohai Sea have been systematically identified (Lv et al., 1993). According to this signage system, the Bohai Sea is divided into several squares and each square has a $1^{\circ} \times 1^{\circ}$ span with a unique place name from China. Every square is further divided into 36 cells with $10^{\prime} \times 10^{\prime}$ span marked with Arabic numerals. Taking the oilfield name of "Penglai 19-3" as an example, the "Penglai 19" shows the position (Fig. 1) and the suffix " -3 " indicates a geologic structure of the seafloor. This study focuses on the central Bohai Sea, including the Caofeidian (CFD), the Bozhong (BZ), and the Penglai (PL) squares (Fig. 1).

\subsection{Underway sampling and analyses}

To clarify the spatial and temporal variations of $\left[\mathrm{CH}_{4}\right]$ in the surface water of the central Bohai Sea, we conducted four field surveys: November 2011, May 2012, July 2012, and August 2012. A modified underway pumping system (Fig. 2) after Pierrot et al. (2009) and Gülzow et al. (2011), in combination with a WS-CRDS $\mathrm{CH}_{4}$ analyzer (model G2301, Picarro Inc., USA), was used to continuously measure $\left[\mathrm{CH}_{4}\right]$ in surface seawater. Surface water was continuously pumped into instruments for analysis from an intake at a depth of $\sim 5 \mathrm{~m}$ (November 2011 and May 2012) or 2-3 m (July and August 2012). The temperature and salinity (Practical Salinity Scale 1978) of the pumped seawater were continuously measured using a calibrated thermosalinograph system (SBE 45, Sea-Bird Inc., USA). The temperature changes during water pumping and transportation were minor $\left(\sim 0.2^{\circ} \mathrm{C}\right)$ and ignored. To determine $\left[\mathrm{CH}_{4}\right]$, pumped water was introduced into a main equilibrator equipped with a spiral nozzle that can create a spray of water and improve equilibration efficiency significantly. A secondary equilibrator was used to pre-equilibrate headspace gas as well as compensate

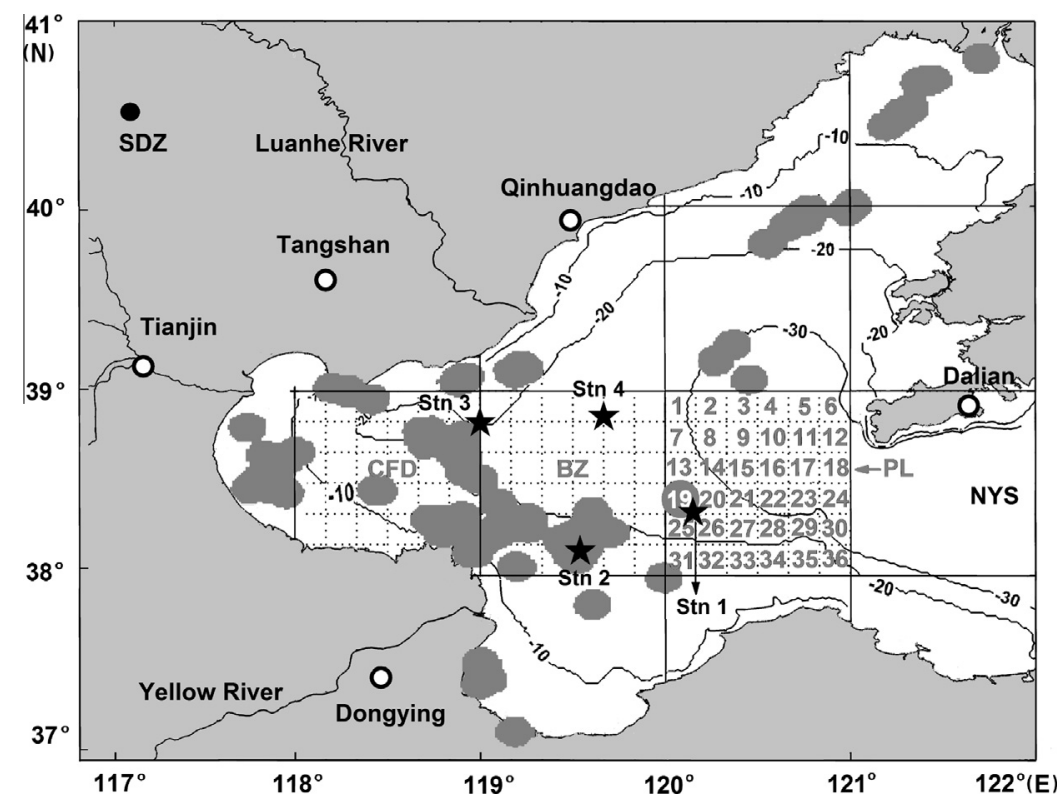

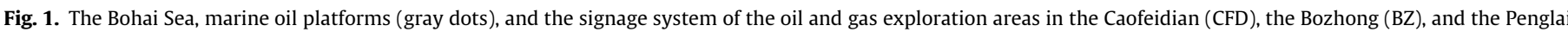

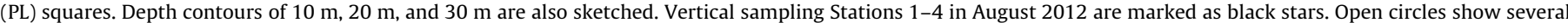

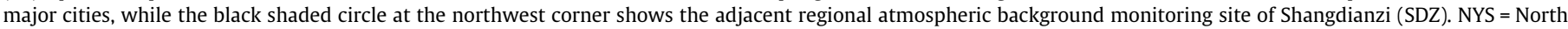
Yellow Sea. 


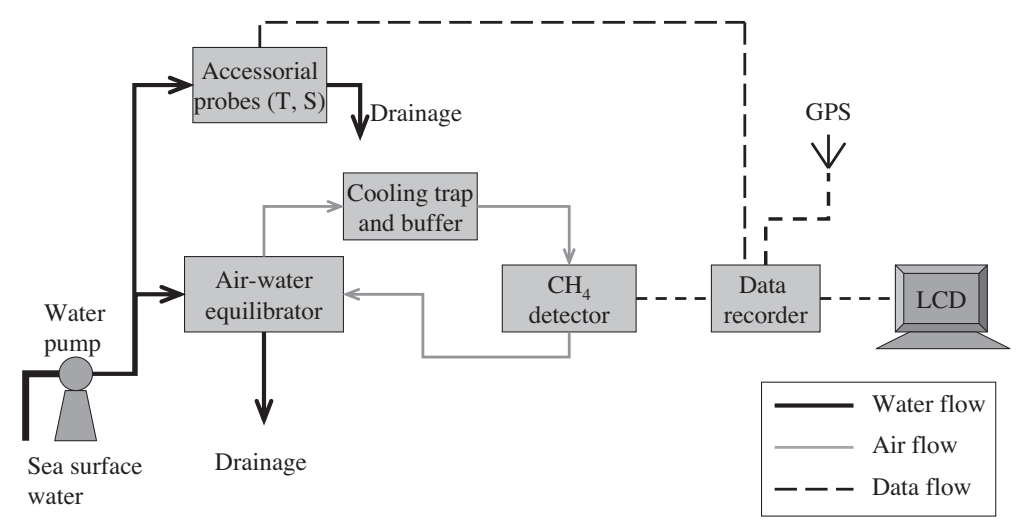

Fig. 2. Schematic diagram of the underway system for continuous determination of dissolved $\mathrm{CH}_{4}$. $\mathrm{LCD}=$ liquid-crystal display.

for gas loss in the main equilibrator. Due to the slowness of $\mathrm{CH}_{4}$ to equilibrate between the gaseous and the water phases, the analysis results are smoothed and delayed by about half an hour (Gülzow et al., 2011, 2013). Hence, with the relatively slow ship speed of 6-10 knots in this study, the worst spatial uncertainty of the underway methane signals was 5 nautical miles.

During analysis, a small amount of air was drawn from the headspace of the main equilibrator. After passing a cooling trap $\left(\sim 10^{\circ} \mathrm{C}\right)$ and a buffer bottle so as to remove a part of the water vapor, the draw-out headspace air was introduced into the WS-CRDS analyzer for the dried $\mathrm{CH}_{4}$ mole fraction $\left(x \mathrm{CH}_{4}\right)$ determination. Finally, the measured air was returned back to the equilibrator so as to balance the inside vacancy. Our WS-CRDS $\mathrm{CH}_{4}$ analyzer can measure individual spectral features without interference from other gas species and water vapor (Crosson, 2008; Zang et al., 2011). Also, built-in pressure and temperature controls make it possible for data collected to be immune to changes in ambient temperature and pressure even in cases of relatively drastic shifts. These qualities have made the WS-CRDS analyzer work stably, suiting continuously underway measurement of $\left[\mathrm{CH}_{4}\right]$ in seawater using ships of opportunity. In this study, the WS-CRDS analyzer was calibrated against two series of gas standards. One series $\left(x \mathrm{CH}_{4}\right.$ from 1.601 to $\left.2.318 \mathrm{ppmv}\right)$ was traceable to the World Meteorological Organization/Background Atmosphere Watch's primary standards (the highest grade), with an uncertainty of $<0.1 \%$ of the contents (Zang et al., 2011, 2013). Another series of gas standards $\left(x \mathrm{CH}_{4}\right.$ from 5.57 to $\left.23.30 \mathrm{ppmv}\right)$ was provided by the China $\mathrm{Na}-$ tional Research Center for Certificated Reference Materials, with overall uncertainty of $<1 \%$ of the contents. Based on these gas standards, we confirmed that our WS-CRDS $\mathrm{CH}_{4}$ analyzer showed a linear response in the range of field-measured sea surface $\mathrm{xCH}_{4}$ values over the surveys (Fig. 3 ).

In July 2012, $\mathrm{CH}_{4}$ concentrations in the air $\left(m_{a t m}\right)$ were measured using the same WS-CRDS analyzer. The bow intake from

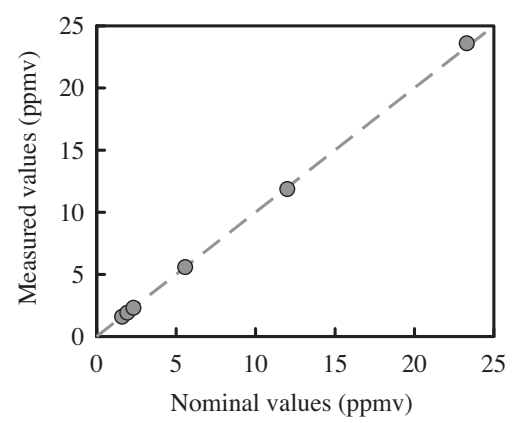

Fig. 3. Linear response of the Picarro $\mathrm{G} 2301 \mathrm{CH}_{4}$ analyzer. The dashed $1: 1$ line is shown. which atmospheric air was pumped was installed at 6-10 $\mathrm{m}$ above the water surface to avoid contamination from the ship's exhaust. Atmospheric air divided from intake air flow was determined for $m_{a t m}$ following the same procedure as that for headspace air mentioned above. The analyzer switched between air and water analyses, with 6 min for air analysis in each hour, except for occasional interruption due to malfunction and maintenance.

\subsection{Vertical profiling and analyses}

To better understand the distribution of $\mathrm{CH}_{4}$ in the central Bohai Sea, we also quantified vertical profiles of $\left[\mathrm{CH}_{4}\right]$ at four stations during the cruise in August 2012 (Fig. 1). Station 1 was situated about $1800 \mathrm{~m}$ away from an inactive oil platform (no gas flaring was observed when sampling) in the Penglai 19 cell (Fig. 1). Station 2 was located about $500 \mathrm{~m}$ away from an active oil platform, indicated by a noticeable gas flaring when sampling. Station 3 was located in the CFD square and Station 4 in the central area away from oil platforms. Discrete samples were taken during upcasts via $2.5 \mathrm{~L}$ Niskin bottles, which were mounted with another ConductivityTemperature-Depth/Pressure (CTD) unit (SBE 19plus, Sea-Bird Inc., USA). Duplicate samples were taken at three to six depths, including the near-surface water layer $(\sim 1.0 \mathrm{~m}$ below the free surface) and the near-bottom water layer ( $\sim 2 \mathrm{~m}$ above the seafloor). Subsamples for $\mathrm{CH}_{4}$ determination were transferred from Niskin bottles into $120 \mathrm{~mL}$ glass bottles using a silicon tube. After overflow of approximately twice the bottle volume, $1 \mathrm{~mL}$ of saturated solution of $\mathrm{HgCl}_{2}$ was added to inhibit microbial activity. Each sample bottle was immediately sealed with a butyl rubber stopper and an aluminum cap to exclude the excessive water, and was stored in the dark. Subsampling was done with care to avoid introducing any air bubbles. All the water samples were analyzed in the land laboratory within 60 days of collection. $\left[\mathrm{CH}_{4}\right]$ was extracted using a gas-stripping method (Swinnerton and Linnenbom, 1967; Zhang et al., 2004). Briefly, $\left[\mathrm{CH}_{4}\right]$ was purged from the seawater, and water vapors and carbon dioxide were removed. Then $\mathrm{CH}_{4}$ was concentrated in a cold U-shaped stainless steel trap packed with 80/100 mesh Porapak Q; the Porapak Q trap was heated and the released $\mathrm{CH}_{4}$ was injected into a Shimadzu GC-14B analyzer and detected by an FID (Zhang et al., 2004). The detection limit is about $0.1 \mathrm{nmol} \mathrm{L}^{-1}$, with overall uncertainty of $<3 \%$ of the contents (Zhang et al., 2004).

\subsection{Data processing}

Following the methodology described in Gülzow et al. (2011), sea surface $\left[\mathrm{CH}_{4}\right]$ in nmol kg-1 was calculated based on Henry's Law:

$\left[\mathrm{CH}_{4}\right]=K_{\mathrm{H}} \times p \mathrm{CH}_{4}$ 
where $K_{\mathrm{H}}$ (unit: $\mathrm{nmol} \mathrm{kg}^{-1} \mathrm{~atm}^{-1}$ ) is the solubility coefficient of $\mathrm{CH}_{4}$ calculated after Wiesenburg and Guinasso (1979), and $\mathrm{pCH}_{4}$ is the partial pressure of $\mathrm{CH}_{4}$ in the headspace of the equilibrator, calculated via Eq. (2).

$p \mathrm{CH}_{4}=x \mathrm{CH}_{4} \times\left[P_{\mathrm{eq}}-\mathrm{VP}\left(\mathrm{H}_{2} \mathrm{O}, \mathrm{sW}\right)\right]$

where $P_{\text {eq }}$ (unit: atm) is the air pressure, and $V P\left(\mathrm{H}_{2} \mathrm{O}\right.$, sw) (unit: atm) is the saturated water vapor pressure in the equilibrator calculated via the Weiss and Price (1980) formula.

The saturation ratios (SR) of $\mathrm{CH}_{4}$ were calculated as:

$\mathrm{SR}(\%)=\left[\mathrm{CH}_{4}\right] /\left[\mathrm{CH}_{4}\right]_{\mathrm{eq}} \times 100$

where $\left[\mathrm{CH}_{4}\right]_{\text {eq }}$ is surface water $\mathrm{CH}_{4}$ concentration in equilibrium with the atmosphere. It was calculated from $m_{a t m}$ data of $\mathrm{CH}_{4}$ and corrected to survey-based barometric pressure at $10 \mathrm{~m}$ above the sea surface and $100 \%$ humidity at in situ sea surface temperature (SST) and sea surface salinity (SSS). Since the field-measured $m_{a t m}$ data of $\mathrm{CH}_{4}$ were unavailable in most cruises, we adopted flask analysis data from the neighboring regional atmospheric background monitoring site of Shangdianzi (SDZ) (Fig. 1) from NOAA/ESRL's Global Monitoring Division (http://www.esrl.noaa.gov/gmd/).

\subsection{Sea-air $\mathrm{CH}_{4}$ flux estimation}

The flux of $\mathrm{CH}_{4}(F)$ across the water-air interface was estimated based on the stagnant laminar layer model of Liss and Slater (1974), which expresses the flux as a product of gas transfer velocity $(k)$ with the difference between measured surface water $\left[\mathrm{CH}_{4}\right]$ and $\left[\mathrm{CH}_{4}\right]_{\text {eq }}$ :

$F=k \times\left(\left[\mathrm{CH}_{4}\right]-\left[\mathrm{CH}_{4}\right]_{\mathrm{eq}}\right) \times \rho_{\mathrm{sw}}$

where $\rho_{\text {sw }}$ (unit: $\mathrm{kg} \mathrm{m}^{-3}$ ) is the density of seawater at a given temperature and salinity. To determine $k$, the revised empirical equation of Wanninkhof (1992) by Sweeney et al. (2007) was used, that is,

$k\left(\mathrm{~cm} \mathrm{~h}^{-1}\right)=0.27 \times\left(u_{10}\right)^{2} \times\left(S_{c} / 660\right)^{-0.5}$

where $S_{c}$ is the Schmidt number in seawater (Wanninkhof, 1992), and $u_{10}$ is the wind speed at $10 \mathrm{~m}$ height (unit: $\mathrm{m} \mathrm{s}^{-1}$ ), recorded by onboard meteorological sensors.

\section{Results and discussion}

\section{1. $\mathrm{CH}_{4}$ concentrations in the air}

The field-measured $m_{a t m}$ of $\mathrm{CH}_{4}$ ranged from 1.92 to $2.31 \mathrm{ppmv}$ during the cruise in July 2012, with an average of 2.07 ppmv. The data reported here were higher than the global mean $\mathrm{CH}_{4}$ concentration in 2011 (1.81 ppmv) (World Meteorological Organization, 2012) and also higher than flask analysis data at the two adjacent regional atmospheric background monitoring sites of SDZ and Taeahn Peninsula (TAP) (Fig. 4). However, our results were consistent with that of Kong et al. (2010) (from 1.87 to 2.61 ppmv in the Tianjin nearshore area). The high $m_{a t m}$ of $\mathrm{CH}_{4}$ in the surveying area may indicate local air addition of $\mathrm{CH}_{4}$ from sea-air emission (see Section 3.4) or from the neighboring industrialized coastal zone (Fig. 1).

At the two adjacent regional atmospheric background monitoring sites, the monthly mean $m_{a t m}$ data of $\mathrm{CH}_{4}$ are usually consistent (Fig. 4), despite the time-lag between the $\mathrm{CH}_{4}$ peak of $1.96 \mathrm{ppmv}$ at the TAP site in July 2011 and the $\mathrm{CH}_{4}$ peak of $2.03 \mathrm{ppmv}$ at the SDZ site in August 2011 (Fig. 4). Their relationships with the Penglai 193 oil-spill accident need further investigation. During our surveying periods, however, monthly mean $m_{\text {atm }}$ data of $\mathrm{CH}_{4}$ varied little from 1.91 to 1.95 ppmv at the neighboring SDZ site (Fig. 4). We adopted them as regional atmospheric background $\mathrm{CH}_{4}$ concentrations of this study (Table 1 ).

\subsection{Spatial and temporal variations of sea surface $\mathrm{CH}_{4}$}

The $\left[\mathrm{CH}_{4}\right]$ in the surface water of the Bohai Sea showed marked variations (Fig. 5, Table 1). $\left[\mathrm{CH}_{4}\right]$ ranged from 2.87 to $12.05 \mathrm{nmol}$ $\mathrm{kg}^{-1}$ in November 2011, with the highest $\left[\mathrm{CH}_{4}\right]$ of $12.05 \mathrm{nmol}$ $\mathrm{kg}^{-1}$ found near the Penglai 19 oilfield (Fig. 5a). In May 2012, $\left[\mathrm{CH}_{4}\right]$ ranged from 3.43 to $16.89 \mathrm{nmol} \mathrm{kg}{ }^{-1}$ (Fig. 5b). The highest value of $16.89 \mathrm{nmol} \mathrm{kg}{ }^{-1}$ was observed in the $\mathrm{BZ}$ square, and the other two hotspots during this cruise were adjacent to the Luanhe estuary and the Yellow River estuary (Fig. 5b). In July 2012, $\left[\mathrm{CH}_{4}\right]$ varied from 2.84 to $6.33 \mathrm{nmol} \mathrm{kg}{ }^{-1}$. The high $\left[\mathrm{CH}_{4}\right]$ area was near several oil-gas platforms, while the relatively low $\left[\mathrm{CH}_{4}\right]$ area was far away from those oil-gas platforms (Fig. 5c). In August 2012, sea surface $\left[\mathrm{CH}_{4}\right]$ ranged from 2.27 to $25.63 \mathrm{nmol} \mathrm{kg}{ }^{-1}$. The most intense surface $\left[\mathrm{CH}_{4}\right]$ peak of $25.63 \mathrm{nmol} \mathrm{kg}{ }^{-1}$ was recorded close to Station 2 (Fig. 5d) when the vessel was approaching an active oil-gas platform. During this cruise, relatively high sea surface $\left[\mathrm{CH}_{4}\right]$ of $5.50-10.77 \mathrm{nmol} \mathrm{kg}{ }^{-1}$ was also revealed in several sea

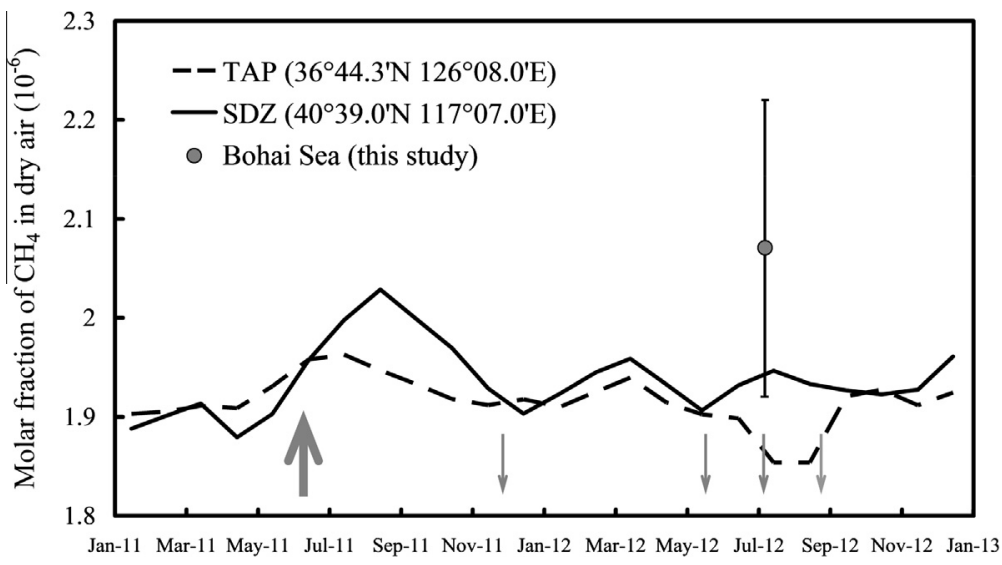

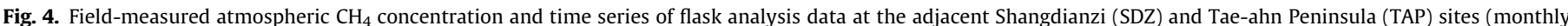

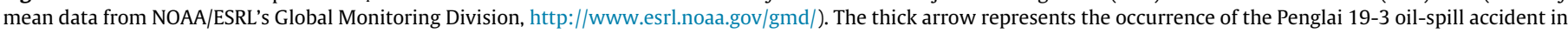
the central Bohai Sea, while thin arrows show our sampling dates. 
Table 1

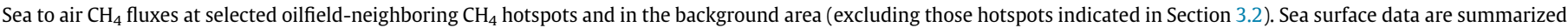

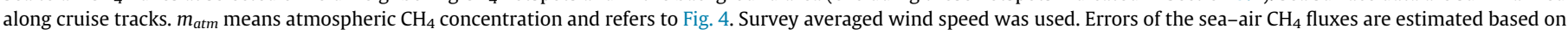
the standard deviations of sea surface dissolved $\mathrm{CH}_{4}$ concentrations.

\begin{tabular}{|c|c|c|c|c|c|c|c|}
\hline Surveying dates & Wind speed $\left(\mathrm{m} \mathrm{s}^{-1}\right)$ & Category & $\begin{array}{l}\mathrm{CH}_{4} \text { concentration } \\
\left(\mathrm{nmol} \mathrm{kg}^{-1}\right)\end{array}$ & $\begin{array}{l}m_{a t m} \\
(\mathrm{ppmv})\end{array}$ & Salinity & Temperature $\left({ }^{\circ} \mathrm{C}\right)$ & $\begin{array}{l}\text { Sea-air fluxes } \\
\left(\mu \mathrm{mol} \mathrm{m}{ }^{-2} \mathrm{~d}^{-1}\right)\end{array}$ \\
\hline \multirow[t]{2}{*}{ November 25-28, 2011} & $4.70 \pm 1.88(1.58-8.38)$ & Background & $\begin{array}{l}3.28 \pm 0.38 \\
(2.87-5.80)\end{array}$ & 1.93 & $\begin{array}{l}30.74 \pm 0.47 \\
(27.96-31.15)\end{array}$ & $\begin{array}{l}13.14 \pm 0.33 \\
(11.82-13.70)\end{array}$ & $0.71 \pm 0.45$ \\
\hline & & Oilfield (PL19) & $\begin{array}{l}11.14 \pm 1.03 \\
(9.18-12.05)\end{array}$ & 1.93 & $\begin{array}{l}31.08 \pm 0.01 \\
(31.07-31.09)\end{array}$ & $\begin{array}{l}13.41 \pm 0.02 \\
(13.38-13.44)\end{array}$ & $10.39 \pm 1.26$ \\
\hline \multirow[t]{2}{*}{ May 16-19, 2012} & $7.4 \pm 2.8(2.2-12.8)$ & Background & $\begin{array}{l}4.37 \pm 0.66 \\
(3.43-6.97)\end{array}$ & 1.91 & $\begin{array}{l}30.53 \pm 0.66 \\
(28.27-31.24)\end{array}$ & $\begin{array}{l}12.3 \pm 1.0 \\
(10.2-15.2)\end{array}$ & $4.89 \pm 2.03$ \\
\hline & & Oilfield (PL19) & $\begin{array}{l}6.60 \pm 0.88 \\
5.25-7.75\end{array}$ & 1.91 & $\begin{array}{l}30.92 \pm 0.29 \\
(30.37-31.21)\end{array}$ & $\begin{array}{l}13.57 \pm 1.36 \\
(11.42-15.19)\end{array}$ & $12.10 \pm 2.57$ \\
\hline \multirow[t]{2}{*}{ July 03-04, 2012} & $3.8^{\mathrm{a}}$ & Background & $\begin{array}{l}3.76 \pm 0.39 \\
(2.84-5.30)\end{array}$ & 1.95 & $\begin{array}{l}30.35 \pm 0.48 \\
(28.92-30.82)\end{array}$ & $\begin{array}{l}22.6 \pm 1.0 \\
(20.6-24.2)\end{array}$ & $1.60 \pm 0.39$ \\
\hline & & Oilfield (CFD) & $\begin{array}{l}5.52 \pm 0.37 \\
4.52-6.33\end{array}$ & 1.95 & $\begin{array}{l}30.60 \pm 0.10 \\
30.34-30.76\end{array}$ & $\begin{array}{l}21.79 \pm 0.62 \\
20.83-23.70\end{array}$ & $3.32 \pm 0.32$ \\
\hline \multirow[t]{3}{*}{ August 23-27, 2012} & $3.8 \pm 1.8(0.9-7.4)$ & Background & $\begin{array}{l}4.24 \pm 0.74 \\
(2.27-8.47)\end{array}$ & 1.93 & $\begin{array}{l}28.28 \pm 1.60 \\
(19.86-29.89)\end{array}$ & $\begin{array}{l}24.4 \pm 0.9 \\
(21.6-26.2)\end{array}$ & $2.27 \pm 0.78$ \\
\hline & & Oilfield (PL19) & $\begin{array}{l}5.12 \pm 0.68 \\
(4.42-6.14)\end{array}$ & 1.93 & $\begin{array}{l}29.48 \pm 0.09 \\
(29.39-29.63)\end{array}$ & $\begin{array}{l}22.42 \pm 0.08 \\
(22.26-22.52)\end{array}$ & $3.00 \pm 0.70$ \\
\hline & & Oilfield (Stn 2) & $\begin{array}{l}19.83 \pm 4.28 \\
(15.71-25.63)\end{array}$ & 1.93 & $\begin{array}{l}29.59 \pm 0.01 \\
(29.58-29.60)\end{array}$ & $\begin{array}{l}23.61 \pm 0.05 \\
(23.54-23.65)\end{array}$ & $18.71 \pm 4.50$ \\
\hline
\end{tabular}

a Using the survey averaged wind speed in August 2012.

Table 2

Summary of sea surface $\mathrm{CH}_{4}$ measurements in the literature.

\begin{tabular}{|c|c|c|c|c|c|c|}
\hline Study area & $\begin{array}{l}\text { Surveying } \\
\text { method }\end{array}$ & Surveying periods & $\begin{array}{l}\text { Surf. }\left[\mathrm{CH}_{4}\right] \\
\left(\mathrm{nmol} \mathrm{L}{ }^{-1}\right)\end{array}$ & Surf. SR (\%) & $\begin{array}{l}\text { Flux } \\
\left(\mu \mathrm{mol} \mathrm{m}{ }^{-2} \mathrm{~d}^{-1}\right)\end{array}$ & References \\
\hline \multicolumn{7}{|l|}{ Chinese coastal seas } \\
\hline Bohai Sea & Underway & November 2011 & $3.42 \pm 1.10^{\mathrm{a}}$ & $127 \pm 41$ & $0.88 \pm 1.36^{\mathrm{e}}$ & This study \\
\hline Bohai Sea & Underway & May 2012 & $5.12 \pm 2.06^{\mathrm{a}}$ & $191 \pm 80$ & $7.26 \pm 6.39^{\mathrm{e}}$ & This study \\
\hline Bohai Sea & Underway & July 2012 & $4.06 \pm 0.77^{a}$ & $183 \pm 33$ & $1.89 \pm 0.76^{\mathrm{e}}$ & This study \\
\hline Bohai Sea & Underway & August 2012 & $4.77 \pm 2.29^{\mathrm{a}}$ & $219 \pm 67$ & $2.82 \pm 2.41^{\mathrm{e}}$ & This study \\
\hline Bohai Sea & 28 Stations & August 2008 & 5.87 & $288 \pm 99$ & $8.1 \pm 4.2^{\mathrm{C}}$ & Li et al. (2010) \\
\hline South Yellow Sea & 14 Stations & March-April 2001 & $3.43 \pm 0.23$ & $121 \pm 5.4$ & $1.33 \pm 0.76^{c}$ & Zhang et al. (2004) \\
\hline East China Sea & 29 Stations & April-May 2001 & $3.24 \pm 0.59$ & $141 \pm 23.6$ & $2.77 \pm 2.71^{\mathrm{c}}$ & Zhang et al. (2004) \\
\hline Northern East China Sea & 21 Stations & September 2003 & $9.4 \pm 11.0$ & $487 \pm 555$ & $36.3 \pm 95.7^{c}$ & Zhang et al. (2008) \\
\hline Northern South China Sea & 55 Stations & September 2006 & $3.8 \pm 1.7$ & $134-297$ & $6.1-51.2^{c}$ & Zhou et al. (2009) \\
\hline \multicolumn{7}{|l|}{ Other coastal and shelf areas } \\
\hline Arabian Sea & 13 Stations & April-May 1994 & No data & $140 \pm 37$ & $0.03 \pm 0.02^{\mathrm{d}}$ & Patra et al. (1998) \\
\hline Arabian Sea & 31 Stations & February-March 1995 & No data & $173 \pm 54$ & $2.65 \pm 3.73^{d}$ & Patra et al. (1998) \\
\hline Arabian Sea & 24 Stations & July-August 1995 & No data & $200 \pm 74$ & $5.02 \pm 4.59^{\mathrm{d}}$ & Patra et al. (1998) \\
\hline Baltic Sea & 63 Stations & February 1992 & No data & $113 \pm 5$ & $9.5-14.7^{\mathrm{d}}$ & Bange et al. (1994) \\
\hline Baltic Sea & 23 Stations & July 1992 & No data & $395 \pm 82$ & $101-1201^{\mathrm{d}}$ & Bange et al. (1994) \\
\hline Bay of Bengal & 47 Stations & January 1994 & $3.85 \pm 7.30^{\mathrm{b}}$ & No data & $2.01 \pm 6.19^{c}$ & Berner et al. (2003) \\
\hline Gulf of Mexico & 207 Stations & August-October 2010 & $1.4 \pm 2.0$ & No data & No data & Kessler et al. (2011) \\
\hline Deepwater Horizon & Underway & June 2010 & 3.3 & 150 & $0.024^{\mathrm{e}}$ & Yvon-Lewis et al. (2011) \\
\hline Japan Sea & 7 Stations & September-October 2007 & $2.6-3.8^{\mathrm{a}}$ & $143 \pm 22$ & $2.64 \pm 1.92^{\mathrm{c}}$ & Gamo et al. (2012) \\
\hline North Sea & 117 Stations & September 1992 & No data & $126 \pm 8$ & $2.16 \pm 1.99^{\mathrm{d}}$ & Bange et al. (1994) \\
\hline North Aegean Sea & $\sim 5$ Stations & July 1993 & $4.80 \pm 0.31$ & $231 \pm 32$ & $1.56^{\mathrm{d}}$ & Bange et al. (1996) \\
\hline Southern Aegean Sea & $\sim 40$ Stations & July 1993 & $3.17 \pm 0.45$ & $149 \pm 18$ & $1.90^{\mathrm{d}}$ & Bange et al. (1996) \\
\hline East Siberian Arctic Shelf & $\begin{array}{l}687 \text { Stations (background), } \\
78 \text { Stations (hotspots) }\end{array}$ & 2003-2008 Summer & $\begin{array}{l}34.4 \text { (background), } \\
292.2 \text { (hotspots) }\end{array}$ & $80-15,000$ & $\begin{array}{l}231.2^{\mathrm{c}} \text { (background), } \\
737.5^{\mathrm{c}} \text { (hotspots) }\end{array}$ & Shakhova et al. (2010) \\
\hline NW Black Sea Shelf & 80 Stations & July-August 1995 & $13.1 \pm 10.6$ & 567 & $53^{\mathrm{c}}$ & Amouroux et al. (2002) \\
\hline
\end{tabular}

${ }^{\text {a }}$ Units in $\mathrm{nmol} \mathrm{kg}^{-1}$.

b Recalculated in this study.

c Air-sea gas transfer velocity was estimated using Wanninkhof (1992) equation.

d Air-sea gas transfer velocity was estimated using Liss and Merlivat (1986) equation.

e Air-sea gas transfer velocity was estimated using Sweeney et al. (2007) equation.

areas near the CFD oilfields, near the Luanhe estuary, and to the west of the Bohai Strait (Fig. 5d).

The surface water was supersaturated with atmospheric $\mathrm{CH}_{4}$ throughout the surveyed areas. SR in surface water of the Bohai Sea varied between $107 \%$ and $448 \%$ in November 2011, $125 \%$ and $643 \%$ in May 2012, $128 \%$ and $280 \%$ in July 2012 , and $108 \%$ and 1193\% in August 2012. The SR sequence was different from that of the averaged surface water temperature of August $\left(24.2^{\circ} \mathrm{C}\right)>$ July $\left(22.4^{\circ} \mathrm{C}\right)>$ November $\left(13.1^{\circ} \mathrm{C}\right)>$ May $\left(12.5^{\circ} \mathrm{C}\right)$. Note that our August 2012 results of sea surface $\left[\mathrm{CH}_{4}\right]$ and SR in the Penglai 19 cell were similar to those values in the same position in summer 2008 (Li et al., 2010).

Sea surface $\left[\mathrm{CH}_{4}\right]$ and SR in the central Bohai Sea were usually comparable to or slightly higher than those reported in other coastal areas (Table 2), although higher $\left[\mathrm{CH}_{4}\right]$ and SR were reported in the northern East China Sea, in the Black Sea shelf, and in the 


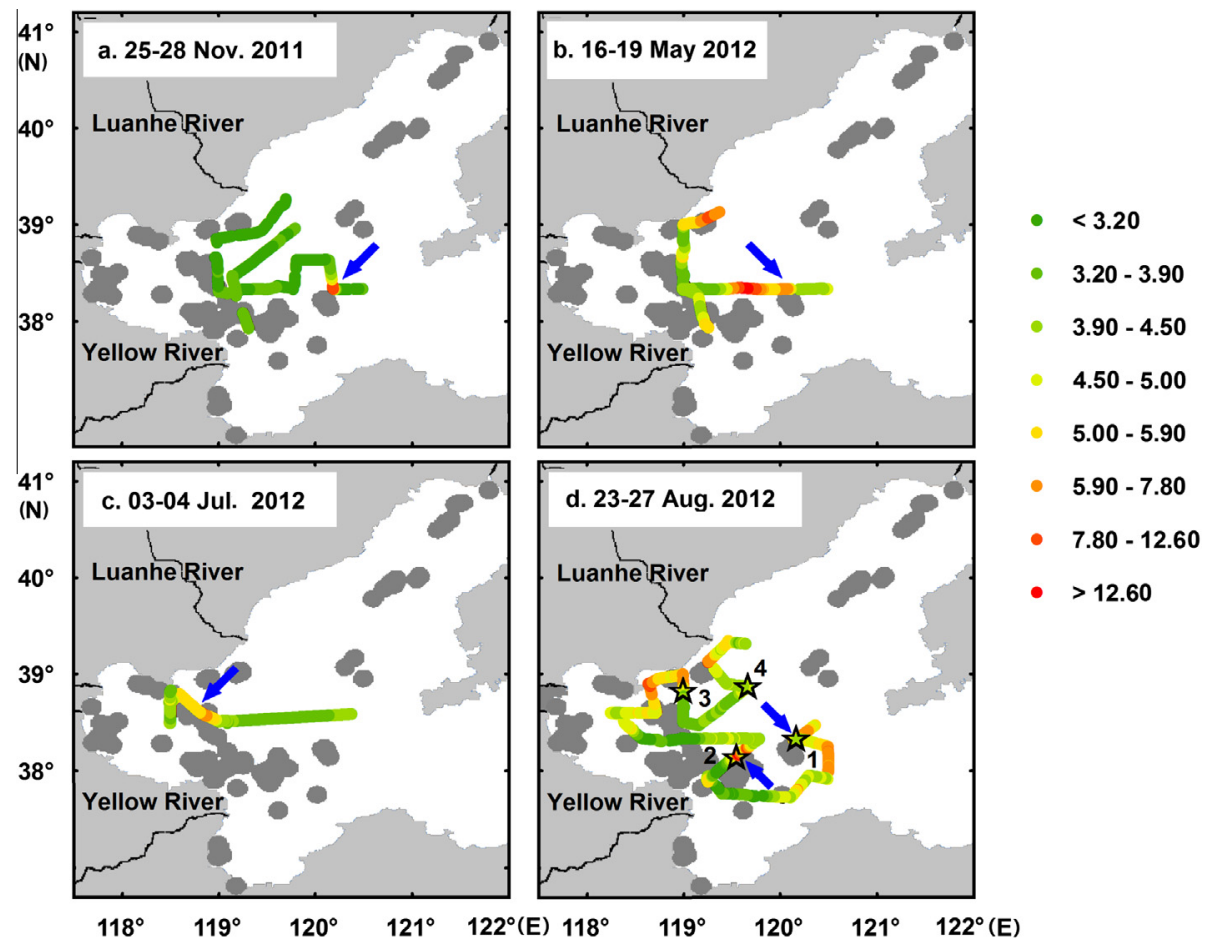

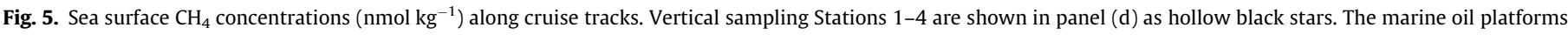

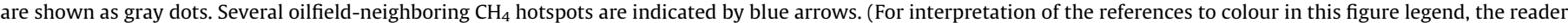
is referred to the web version of this article.)

East Siberian Arctic Shelf. In the northern East China Sea, $\mathrm{CH}_{4}$-rich effluents from the Yangtze River support the very high surface water $\left[\mathrm{CH}_{4}\right]$ (Zhang et al., 2008). In the Black Sea shelf, anaerobic metabolism together with numerous methane-emitting bottom features, such as seeps, methane clathrate hydrates, and mud volcanoes, sustain the high sea surface $\left[\mathrm{CH}_{4}\right]$ in this, the world's largest anoxic basin (Amouroux et al., 2002). In the East Siberian Arctic Shelf, seabed permafrost releases $\mathrm{CH}_{4}$ to the water column (Shakhova et al., 2010).

Around the Bohai Sea, the Yellow River water has been reported to contain high $\left[\mathrm{CH}_{4}\right]$ ( $\mathrm{Li}$ et al., 2010; Gu et al., 2011). The input of $\mathrm{CH}_{4}$-rich river water may elevate the $\mathrm{CH}_{4}$ levels in coastal waters near the Yellow River estuary and the Luanhe River estuary. Additionally, several marine oil platforms are located in the Luanhe estuary and the northern part of the Yellow River estuary (Fig. 5). The sediment near these two estuaries has been intensely contaminated by petroleum (Hu et al., 2013a) and spills of oil products (Hu et al., 2013b). Therefore, it is reasonable to say that the highly fluctuating $\left[\mathrm{CH}_{4}\right]$ in the nearshore areas was caused by the combined influences of land inputs and in situ petroleum contamination.

In the central Bohai Sea, however, the river input of $\mathrm{CH}_{4}$ is negligible. The tremendous heterogeneity of sea surface $\left[\mathrm{CH}_{4}\right]$ distributions (Fig. 5) may indicate gas leakage from the seafloor, which shall be verified by the vertical profiles of $\mathrm{CH}_{4}$ in the water column, as described in Section 3.3.

\subsection{Bottom-up transportation of $\mathrm{CH}_{4}$}

In a summer cruise in August 2012, the two-layer summer stratification (with a warmer surface layer and a colder bottom layer) was not always observed at selected stations (Fig. 6). However, the bottom layer $\left[\mathrm{CH}_{4}\right]$ was usually higher than that in the surface layer, indicating a rapid bottom-up transport mechanism (Reeburgh, 2007). At Stations 3 and 4 with the strongest water stratification, SST was $3.38^{\circ} \mathrm{C}$ and $2.38^{\circ} \mathrm{C}$ higher than the bottom temperature, respectively, while $\left[\mathrm{CH}_{4}\right]$ was relatively low and homogeneous, changing from $7.39 \mathrm{nmol} \mathrm{kg}^{-1}$ (Station 3) or 7.87

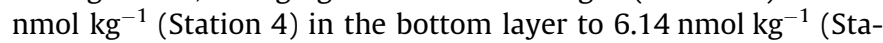
tion 3) or $5.11 \mathrm{nmol} \mathrm{kg}^{-1}$ (Station 4) in the surface layer (Fig. 6). In contrast, at the weakly stratified Station 1 , with the surface water $1.61{ }^{\circ} \mathrm{C}$ warmer than the bottom water, $\left[\mathrm{CH}_{4}\right]$ declined greatly from $11.97 \mathrm{nmol} \mathrm{kg}^{-1}$ in the bottom layer to $6.19 \mathrm{nmol} \mathrm{kg}^{-1}$ in the surface layer (Fig. 6).

At Station 2, approximately $500 \mathrm{~m}$ away from an active oil-gas platform, the water column was well mixed, as indicated by homogeneous vertical profiles of temperature and salinity (Fig. 6). However, $\left[\mathrm{CH}_{4}\right]$ showed a highly stratified pattern. $\left[\mathrm{CH}_{4}\right]$ increased from the sea surface $13.87 \mathrm{nmol} \mathrm{kg}^{-1}$ to a maximum of $28.67 \mathrm{nmol} \mathrm{kg}^{-1}$ at $10 \mathrm{~m}$ depth. From the $\mathrm{CH}_{4}$ maximum depth to the bottom layer, $\left[\mathrm{CH}_{4}\right]$ varied very little (Fig. 6). The highest $\left[\mathrm{CH}_{4}\right]$ value in the water column of Station 2 was 1.4-3.0 times higher than at the other stations, and the corresponding underway sea surface $\left[\mathrm{CH}_{4}\right]$ data ranged from 15.71 to $25.63 \mathrm{nmol} \mathrm{kg}^{-1}$, indicating a very strong $\mathrm{CH}_{4}$ source nearby.

Therefore, it is reasonable to say that the central Bohai Sea was laden with $\mathrm{CH}_{4}$ in the spring, summer, and autumn periods of measurement. Additional $\mathrm{CH}_{4}$ leaked from the seafloor and mixed up to the sea surface, leading to enhanced methane signals in the study area.

Another piece of evidence pointing to the bottom-up transportation of $\mathrm{CH}_{4}$ is derived from underway SST and SSS distributions. Around those selected oilfield-neighboring $\mathrm{CH}_{4}$ hotspots, SSS was always higher than that in the background area (surveyed areas excluding those hotspots indicated in Section 3.2), while SST was higher than that in the background area in the colder months (November and May) and lower in the warmer months (July and August) (Table 1). The oilfield-neighboring high $\mathrm{CH}_{4}$ associated with abnormal SSS and SST indicated upwelling or vertical mixing of the water column, presumably driven by gas seepages and/or oil spills at the seafloor, similar to the upwelling-associated high $\mathrm{CH}_{4}$ signals in surface water off Oregon (Rehder et al., 2002) and in the Baltic Sea (Gülzow et al., 2013). 
Since the average depth of the Bohai Sea is only $18 \mathrm{~m}$, the water column provides a short conduit for the seafloor-released $\mathrm{CH}_{4}$ to rise to the surface layer. Although microbial consumption has been realized as a significant sink for spilled $\mathrm{CH}_{4}$ in deep oceans (Westbrook et al., 2009; Kessler et al., 2011; Schmale et al., 2011), the strength of this process remains to be assessed in shallow sea areas such as the Bohai Sea.

3.4. Sea-air $\mathrm{CH}_{4}$ fluxes and impacts of episodic oil-gas spills on $\mathrm{CH}_{4}$ degassing in the Bohai Sea

To clarify the impacts of episodic oil-gas spills on $\mathrm{CH}_{4}$ degassing, we calculated sea-air $\mathrm{CH}_{4}$ fluxes at selected oilfield-neighboring hotspots and in the background area separately. The $m_{a t m}$ was obtained from the monthly mean data at the neighboring regional atmospheric background monitoring site of Shangdianzi (Fig. 1).

Table 1 summarizes the sea-air $\mathrm{CH}_{4}$ flux estimation along the cruise tracks. In general, the survey averages of sea-air $\mathrm{CH}_{4}$ fluxes in the background area followed the order May $>$ August $>$ July $>$ November, in line with the sequence of sea surface $\left[\mathrm{CH}_{4}\right]$ (Table 1 ). There was no doubt that the $\mathrm{CH}_{4}$ hotspots mentioned in Section 3.2 showed enhanced $\mathrm{CH}_{4}$ fluxes compared with the background area. In the spring and summer seasons, the survey averages of sea-air $\mathrm{CH}_{4}$ fluxes in this study $\left(1.60-18.71 \mu \mathrm{mol} \mathrm{m} \mathrm{m}^{-2} \mathrm{~d}^{-1}\right)$ were slightly higher than those in the Baltic Sea $\left(0.69-14.00 \mu \mathrm{mol} \mathrm{m}{ }^{-2} \mathrm{~d}^{-1}\right)$ (Gülzow et al., 2013). However, results from the present study in November (0.71-10.39 $\mu \mathrm{mol} \mathrm{m} \mathrm{m}^{-2} \mathrm{~d}^{-1}$ ) were much lower than those during the winter season in the Baltic Sea $(1.30-98.93 \mu \mathrm{mol}$ $\mathrm{m}^{-2} \mathrm{~d}^{-1}$ ) (Gülzow et al., 2013).

The "Penglai 19-3" oil-spill accident occurred in June 2011 and lasted for several months, affecting a large area of ca. $6200 \mathrm{~km}^{2}$, from the water nearby "Penglai 19" oilfield to coastal waters of Tangshan and Qinhuangdao Cities (State Oceanic Administration of China, 2012). In November 2011, i.e., 5 months after the accident first occurred, a high sea surface $\left[\mathrm{CH}_{4}\right]$ level of $11.14 \pm 1.03 \mathrm{nmol} \mathrm{kg}^{-1}$ (3.4 times the background level) was still observed in the vicinity of the oil platform. In the next year, sea surface $\left[\mathrm{CH}_{4}\right]$ declined to $6.60 \pm 0.88 \mathrm{nmol} \mathrm{kg}^{-1}$ (1.5 times the background level) in May, and to $5.12 \pm 0.68 \mathrm{nmol} \mathrm{kg}^{-1}$ (1.2 times the background level) in August (Table 1 ). The sea-air $\mathrm{CH}_{4}$ fluxes in the vicinity of the Penglai 19 oilfield were 14.6 times the background value in November 2011, 2.5 times in May 2012, and almost declined to the background level in August 2012 (Fig. 7), indicating that impacts of the oil spill on sea-air $\mathrm{CH}_{4}$ fluxes had essentially disappeared by the time of our study. The sea-air flux of $\mathrm{CH}_{4}$ in August $2012\left(3.00 \pm 0.70 \mu \mathrm{mol} \mathrm{m}^{-2} \mathrm{~d}^{-1}\right)$ was fairly comparable to the value prior to the oil spill, based on data obtained in summer 2008 (Li et al., 2010).

The CFD oilfield also displayed high surface $\left[\mathrm{CH}_{4}\right]$ and enhanced sea-air $\mathrm{CH}_{4}$ fluxes in July/August 2012, compared with the background levels (Table 1 and Fig. 5). In the BZ square, the oilfield-induced $\mathrm{CH}_{4}$ release was observed near Station 2 in August 2012 , where surface $\left[\mathrm{CH}_{4}\right]$ was greatly elevated to $19.83 \pm 4.28$ $\mathrm{nmol} \mathrm{kg} \mathrm{kg}^{-1}$ (4.7 times the background level) and the sea-air flux increased to an intense value of $18.71 \pm 4.50 \mu \mathrm{mol} \mathrm{m}^{-2} \mathrm{~d}^{-1}(8.2$ times the background level).

Although sea-air $\mathrm{CH}_{4}$ flux estimation is subjected to uncertainty in the assessment of gas transfer velocity and hydrodynamic conditions (Wanninkhof et al., 2009; Johnson et al., 2011), sea-air $\mathrm{CH}_{4}$ fluxes in the Bohai Sea fell within the range of those in the
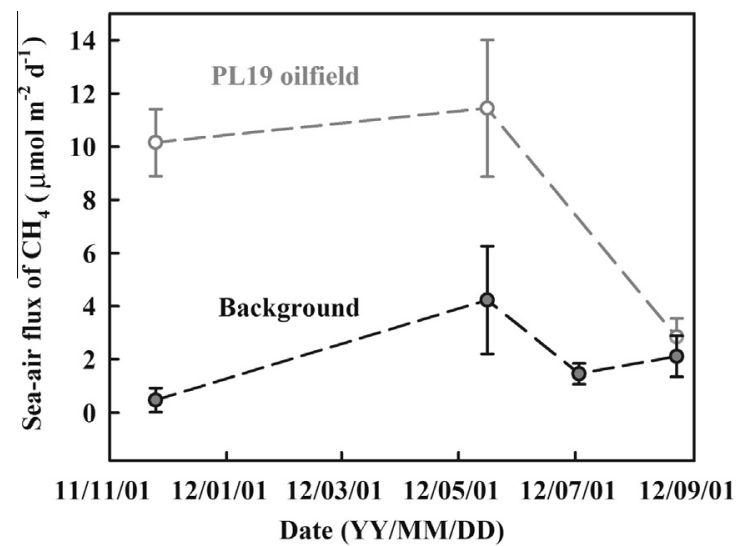

Fig. 7. Evolution of sea to air fluxes of $\mathrm{CH}_{4}$ in the Penglai 19 cell and in the background area (surveyed areas excluding those hotspots indicated in Section 3.2).
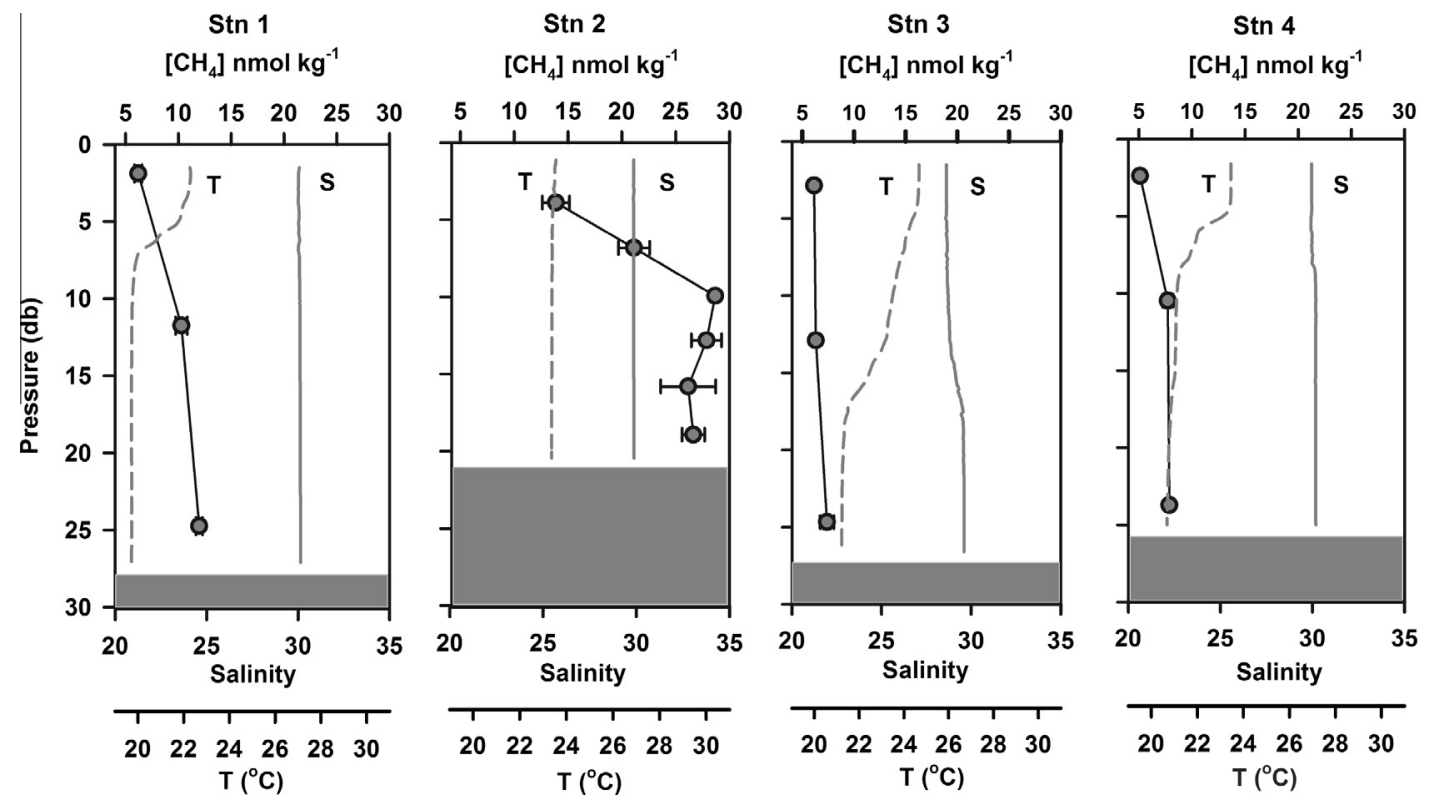

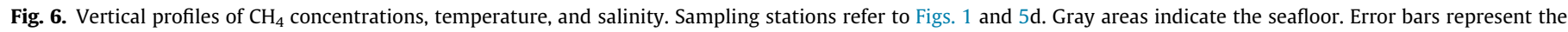
data range of duplicate water samples. 
world coastal and shelf areas (Table 2). The fluxes in the background area fell to the lower limit while the fluxes in hotspots were in the median to high level (Table 1 vs. Table 2).

In summary, the central Bohai Sea served as a net source of atmospheric methane during the survey periods. Episodic oil-gas spills at the seafloor of the Bohai Sea penetrated the water columns, increasing surface $\left[\mathrm{CH}_{4}\right]$ by up to 4.7 times and enhancing sea-air $\mathrm{CH}_{4}$ flux by up to 14.6 times. This was quite different from the case of the 2010 Deepwater Horizon oil spill in the Gulf of Mexico, where the spilled $\mathrm{CH}_{4}$ was trapped and consumed in deep water, leaving $<0.01 \%$ of the emitted $\mathrm{CH}_{4}$ to escape to the atmosphere during active flow (Kessler et al., 2011; Yvon-Lewis et al., 2011). However, the influence of episodic oil-gas spills on $\mathrm{CH}_{4}$ degassing decreased gradually as time went by in the central Bohai Sea.

\section{Concluding remarks}

The high-resolution measurements in the central Bohai Sea showed tremendously spatiotemporal variations of sea surface $\mathrm{CH}_{4}$ due to land inputs and local petroleum contamination. The Bohai Sea served as a net source of atmospheric methane during the survey periods. Human activities associated with marine oil and gas exploration induced $\mathrm{CH}_{4}$ release from the seafloor, leading to increased $\mathrm{CH}_{4}$ concentrations in surface water and enhanced $\mathrm{CH}_{4}$ emission to the atmosphere. More efforts are needed to better evaluate sea-air fluxes of $\mathrm{CH}_{4}$ in shallow-water oil and gas exploration areas in the world.

\section{Acknowledgements}

We thank Guiling Zhang's group for laboratory analyses of some water samples of $\mathrm{CH}_{4}$, Zhihua Liu and Zhaolin Chen for the data collection in July 2012, Prof. Huixiang Xie, Prof. Charles Sheppard, and an anonymous reviewer for their valuable comments on the manuscript, and Cathryn Primrose-Mathisen for her assistance with English. Cheng Huo, Houjie Wang and crews of $R / V$ Dongfanghong 2 and $R / V$ Yixing provided much help during the sampling surveys. The research was supported by the National Natural Science Foundation of China (NSFC) through Grants 41006040 and 41276061 , and by the Key Laboratory for Ecological Environment in Coastal Areas, State Oceanic Administration of China (Contract 201203), by the open fund of SOA Key Laboratory of Global Change and MarineAtmospheric Chemistry (Contract GCMAC1207). Sampling cruises were separately supported by the NSFC Open Ship-time projects, the National Basic Research Program of China (2009CB421204), and the pilot project of the State Oceanic Administration of China on air-sea $\mathrm{CO}_{2}$ flux monitoring in the North Yellow Sea.

\section{References}

Amouroux, D., Roberts, G., Rapsomanikis, S., et al., 2002. Biogenic gas $\left(\mathrm{CH}_{4}, \mathrm{~N}_{2} \mathrm{O}\right.$, DMS) emission to the atmosphere from near-shore and shelf waters of the north-western Black Sea. Estuar. Coast. Shelf Sci. 54, 575-587.

Bange, H.W., Bartell, U.H., Rapsomanikis, S., et al., 1994. Methane in the Baltic and North Seas and a reassessment of the marine emissions of methane. Global Biogeochem. Cycles 8, 465-480.

Bange, H.W., Rapsomanikis, S., Anderae, M.O., 1996. The Aegean sea as a source of atmospheric nitrous oxide and methane. Mar. Chem. 53, 41-49.

Bernard, B.B., Brooks, J.M., Sackett, W.M., 1976. Natural gas seepage in the Gulf of Mexico. Earth Planet. Sci. Lett. 31, 48-54.

Berner, U., Poggenburg, J., Faber, E., et al., 2003. Methane in ocean waters of the Bay of Bengal: its sources and exchange with the atmosphere. Deep-Sea Res. II 50, 925-950.

Blake, R.B., Rowland, F.S., 1988. Continuing worldwide increase in tropospheric methane, 1978-1987. Science 239, 1129-1131.

CCICED (China Council for International Cooperation on Environment and Development), 2010. Ecosystem issues and policy opinions addressing sustainable development of China's ocean and coast. <http://www.cciced.net/ encciced/policyresearch/report/>.
Chen, H., Winderlich, J., Gerbig, C., et al., 2010. High-accuracy continuous airborne measurements of greenhouse gases $\left(\mathrm{CO}_{2}\right.$ and $\left.\mathrm{CH}_{4}\right)$ using the cavity ring-down spectroscopy (CRDS) technique. Atmos. Meas. Technol. 3, 375-386.

Cline, J.D., Katz, C.N., Kelly-Hansen, K., 1986. Seasonal cycles of dissolved methane in the southeastern Bering Sea. In: Sohn, M.L., (Ed.), Organic Marine Geochemistry, ACS Symposium Series, vol. 305, 272-296.

Conrad, R., Seiler, W., 1988. Influence of the surface microlayer on the flux of nonconservative trace gases $\left(\mathrm{CO}, \mathrm{H}_{2}, \mathrm{CH}_{4}, \mathrm{~N}_{2} \mathrm{O}\right)$ across the ocean-atmosphere interface. J. Atmos. Chem. 6, 83-94.

Crosson, E.R., 2008. A cavity ring-down analyzer for measuring atmospheric levels of methane, carbon dioxide, and water vapor. Appl. Phys. B 92, 403-408.

Crutzen, P.J., 1991. Methane's sinks and sources. Nature 350, 380-381.

Damm, E., Helmke, E., Thoms, S., et al., 2010. Methane production in aerobic oligotrophic surface water in the central Arctic Ocean. Biogeosciences 7, 10991108.

Gamo, T., Tsunogai, U., Hirota, A., et al., 2012. First measurements of methane and its carbon isotope ratio in the Japan Sea (East Sea). Mar. Chem. 128-129, 92-99.

Gu, P.P., Zhang, G.L., Li, P.P., et al., 2011. Effect of the water-sediment regulation on dissolved methane in the lower Yellow River estuary and its adjacent marine area (in Chinese). China Environ. Sci. 31, 1821-1828.

Gülzow, W., Rehder, G., Schneider, B., et al., 2011. A new method for continuous measurement of methane and carbon dioxide in surface waters using off-axis integrated cavity output spectroscopy (ICOS): an example from the Baltic Sea. Limnol. Oceanogr. Methods 9, 176-184.

Gülzow, W., Rehder, G., Schneider, v., Deimling, J., 2013. One year of continuous measurements constraining methane emissions from the Baltic Sea to the atmosphere using a ship opportunity. Biogeosciences 10, 81-99.

Houghton, J.T., Jenkins, G.J., Ephramus, J.J., 1990. Climate Change: The IPCC Scientific Assessment. Cambridge University Press, Cambridge.

Hu, L.M., Liu, J.H., Shi, X.F., et al., 2013a. Petroleum contamination in the surface sediments of the Bohai Sea: evidence from the sedimentary biomarker records (in Chinese). Acta Oceanol. Sin. 35 (1), 121-130.

Hu, N.J., Huang, P., Liu, J.H., et al., 2013b. Source apportionment of polycyclic aromatic hydrocarbons in surface sediments of the Bohai Sea. China Environ. Sci. Pollut. Res. 20, 1031-1040.

IPCC, 2007. Contribution of working group I to the fourth assessment report of the intergovernmental panel on climate change. In: Solomon, S., Oin, D.H., Manning, M., et al. (Eds.), Climate Change 2007: The Physical Science Basis. Cambridge University Press.

Johnson, M.T., Hughes, C., Bell, T.G., Liss, P.S., 2011. A Rumsfeldian analysis of uncertainty in air-sea gas exchange. In: Gas Transfer at Water Surfaces. Kyoto University Press, pp. 464-485.

Jones, R.D., 1991. Carbon monoxide and methane distribution and consumption in the photic zone of the Sargasso Sea. Deep-Sea Res. 38, 625-635.

Karl, D.M., Beversdorf, L., Bjorkman, K.M., et al., 2008. Aerobic production of methane in the sea. Nat. Geosci. 1, 473-478.

Kessler, J.D., Valentine, D.L., Redmond, M.C., et al., 2011. A persistent oxygen anomaly reveals the fate of spilled methane in the deep Gulf of Mexico. Science 331, 312-315.

Kong, S.F., Lu, B., Han, B., et al., 2010. Seasonal variation analysis of atmospheric $\mathrm{CH}_{4}$ $\mathrm{N}_{2} \mathrm{O}$ and $\mathrm{CO}_{2}$ in Tianjin offshore area. Sci. China Earth Sci. 53, 1205-1215.

Kou, M., Jia, Y.G., Liu, W.Q., 2010. Development of a GIS-based oil spill emergency equipment dispatching system (in Chinese). Environ. Eng. 28 (Suppl), 356-359.

Lamontagne, R.A., Swinnerton, J.W., Linnenbom, V.J., et al., 1973. Methane concentrations in various marine environments. J. Geophys. Res. 78, 5317 5324.

Lelieveld, J., Crutzen, P.J., Dentener, F.J., 1998. Changing concentration, lifetime and climate forcing of atmospheric methane. Tellus B-Chem. Phys. Meteorol. 50, $128-150$

Li, P.P., Zhang, G.L., Zhao, Y.C., Liu, S.M., 2010. Study on distributions and flux of methane dissolved in the Bohai Sea in summer (in Chinese). Adv. Mar. Sci. 28, 478-487.

Liss, P.S., Merlivat, L., 1986. Air-sea gas exchange rates: introduction and synthesis In: Buat-Ménard, P. (Ed.), The Role of Air-Sea Exchange in Geochemica Cyclings, NATO ASI Series 185. Springer, Netherlands, pp. 113-127.

Liss, P.S., Slater, P.G., 1974. Flux of gases across the air-sea interface. Nature 247, $181-184$

Lv, Q.Z., Wang, P.Y., Li, F.X., et al., 1993. Oil fields in the Bohai Sea (in Chinese) Tianjin People's Publishing House, Tianjin, China.

Martens, C.S., Berner, R.A., 1974. Methane production in the interstitial waters of sulphate-depleted marine sediments. Science 185, 1167-1169.

Martens, C.S., Klump, J.V., 1980. Biogeochemical cycling in the organic-rich coastal marine basin - I. Methane sediment-water exchange processes. Geochim. Cosmochim. Acta 44, 471-490.

Patra, P.K. Lal, S., Venkataramani, S., et al., 1998. Seasonal variability in distribution and fluxes of methane in the Arabian Sea. J. Geophys. Res. 103, 1167-1176.

Pierrot, D., Neill, C., Sullivan, K., et al., 2009. Recommendations for autonomous underway $\mathrm{pCO}_{2}$ measuring systems and data-reduction routines. Deep-Sea Res. II 56, 512-522.

Plass-Dülmer, C., Kehdim, A., Koppmann, R., et al., 1993. Emission of light nonmethane hydrocarbons from the Atlantic into the atmosphere. Global Biogeochem. Cycles 7, 211-228.

Plass-Dülmer, C., Koppmann, R., Ratte, M., et al., 1995. Light nonmethane hydrocarbons in seawater. Global Biogeochem. Cycles 9, 79-100.

Reeburgh, W.S., 2007. Oceanic methane biogeochemistry. Chem. Rev. 107, 486-513. 
Reed, W.E., Kaplan, I.R., 1977. The chemistry of marine petroleum seeps. J. Geochem. Explor. 7, 255-293.

Rehder, G., Keir, R.S., Suess, E., et al., 1998. The multiple sources and patterns of methane in North Sea waters. Aquat. Geochem. 4, 403-427.

Rehder, G., Collier, R.W., Heeschen, K., et al., 2002. Enhanced marine $\mathrm{CH}_{4}$ emissions to the atmosphere off Oregon caused by coastal upwelling. Global Biogeochem. Cycles 16, 1081. http://dx.doi.org/10.1029/2000GB001391.

Sackett, W.M., Brooks, J.M., 1975. Origin and distributions of low molecular weight hydrocarbons in Gulf of Mexico coastal waters. In: Church, T.M., (Ed.), Marine Chemistry in the Coastal Environment, ACS Symposium Series, vol. 18, 211-230.

Schmale, O., Haeckel, M., McGinnis, D.F., 2011. Response of the Black Sea methane budget to massive short-term submarine inputs of methane. Biogeosciences 8 , 911-918.

Shakhova, N., Semiletov, I., Salyuk, A., et al., 2010. Extensive methane venting to the atmosphere from sediments of the East Siberian Arctic Shelf. Science 327, 1246-1250.

Shindell, D.T., Faluvegi, G., Koch, D.M., et al., 2009. Improved attribution of climate forcing to emissions. Science 326, 716-718.

Sieburth, J.N., Johnson, P.W., Eberhardt, M.A., et al., 1987. The first methaneoxidizing bacterium from the upper nixing layer of the deep ocean: Methylomonas pelagica sp. nov. Curr. Microbial. 14, 285-293.

State Oceanic Administration of China, 2012. Bulletin of Marine Environmenta Status of China in 2011 (in Chinese). <http://www.soa.gov.cn/zwgk/hygb/ zghyhjzlgb/>.

Sweeney, C., Gloor, E., Jacobson, A.R., et al., 2007. Constraining global air-sea gas exchange for $\mathrm{CO}_{2}$ with recent bomb ${ }^{14} \mathrm{C}$ measurements. Global Biogeochem. Cycles 21, GB2015. doi: 10.1029/2006GB002784.

Swinnerton, J.W., Linnenbom, V.J., 1967. Determination of C1-C4 hydrocarbons in seawater by gas chromatography. J. Gas Chromatogr. 5, 570-573.

Valentine, D., 2010. Measure methane to quantify the oil spill. Nature 465, 421-421.

Valentine, D.L., Kessler, J.D., Redmond, M.C., et al., 2010. Propane respiration jumpstarts microbial response to a deep oil spill. Science 330, 208-211.

Wanninkhof, R., 1992. Relationship between wind speed and gas exchange over the ocean. J. Geophys. Res. 97, 7373-7382.
Wanninkhof, R., Asher, W.E., Ho, D.T., et al., 2009. Advances in quantifying air-sea gas exchange and environmental forcing. Annu. Rev. Mar. Sci. 1, 213-244.

Weiss, R.F., Price, B.A., 1980. Nitrous oxide solubility in water and seawater. Mar. Chem. 8, 347-359.

Westbrook, G.K., Thatcher, K.E., Rohling, E.J., et al., 2009. Escape of methane gas from the seabed along the West Spitsbergen continental margin. Geophys. Res. Lett. 36, L15608. http://dx.doi.org/10.1029/2009GL039191.

Wiesenburg, D.A., Guinasso Jr., N.L., 1979. Equilibrium solubilities of methane, carbon monoxide and hydrogen in water and seawater. J. Chem. Eng. Data 24, 356-360.

Winderlich, J., Chen, H., Gerbig, C., et al., 2010. Continuous low-maintenance $\mathrm{CO}_{2}$ / $\mathrm{CH}_{4} / \mathrm{H}_{2} \mathrm{O}$ measurements at the Zotino Tall Tower Observatory (ZOTTO) in Central Siberia. Atmos. Meas. Technol. 3, 1113-1128.

World Meteorological Organization, 2012. Greenhouse Gas, Bulletin, No. 8, pp. 1-4.

Yvon-Lewis, S.A., Hu, L., Kessler, J., 2011. Methane flux to the atmosphere from the deepwater horizon oil disaster. Geophys. Res. Lett. 38, L01602. http:// dx.doi.org/10.1029/2010GL045928.

Zang, K.P., Zhou, L.X., Fang, S.X., et al., 2011. A new system for calibration and propagation of mixed $\mathrm{CO}_{2}$ and $\mathrm{CH}_{4}$ standards (in Chinese). Environ. Chem. 30, 511-516.

Zang, K.P., Zhao, H.D., Wang, J.Y., et al., 2013. High-resolution measurement of $\mathrm{CH}_{4}$ in sea surface air based on cavity ring-down spectroscopy technique: the first try in China Seas (in Chinese). Acta Sci. Circumst. 33, 1362-1366.

Zhang, G.L., Zhang, J., Kang, Y.B., et al., 2004. Distributions and fluxes of methane in the East China Sea and the Yellow Sea in spring. J. Geophys. Res. 109, C07011. http://dx.doi.org/10.1029/2004JC002268.

Zhang, G.L., Zhang, J., Liu, S.M., et al., 2008. Methane in the Changjiang (Yangtze River) estuary and its adjacent marine area: riverine input, sediment release and atmospheric fluxes. Biogeochemistry 91, 71-84.

Zhou, H.Y., Yin, X.J., Yang, Q.H., et al., 2009. Distribution, source and flux of methane in the western Pearl River estuary and northern South China Sea. Mar. Chem. $117,21-31$. 